\title{
Between Alpine Identity and Civic Duty: Encounters with Swiss Brethren in Rudolf von Tavel's Historical Novel Der Frondeur (1929)
}

\author{
Berit Jany \\ Senior Instructor \& Language Coordinator \\ Department of Germanic and Slavic Languages and Literature \\ University of Colorado, Boulder
}

\begin{abstract}
The history of seventeenth-century Swiss Brethren in the State of Bern has been one of growth, persecution, and support from sympathetic neighbors. Their struggles and persistence have inspired a number of authors to produce fictional narratives dealing with the brethren in their Bernese homeland. This article examines Rudolf von Tavel's historical novel Der Frondeur (1929), in which he depicts the persecuted brotherhood in Bern. The following analysis exposes the way in which the author has fictionalized the Anabaptist group, its commitment to theological and ethical aspects, and the experience of persecution. In particular, the study investigates which characteristics drawn from Ernst Müller's historical account of the Swiss Brethren have been modified and adjusted to serve Tavel's storyline. As a result, my study reveals the author's underlying concept of civic duty and the formation of a Swiss national identity cloaked by his literary articulation of encounters between the Bernese society and the religious minority.
\end{abstract}

\section{Keywords}

Mennonite; Berne, Switzerland; National identity; Fiction; Seventeenth century 


\section{The Swiss Brethren in Regional Historical Writing}

As alternative reformers seeking to establish an ideal Christian community, characterized by believer's baptism, non-resistance, and the refusal to participate in civil government, the Swiss Brethren ${ }^{1}$ were perceived as dissidents by the dominant society of seventeenth-century Switzerland. The radical reform movement had risen and spread quickly in the State of Bern, ${ }^{2}$ especially in the region of the Emmental. Witnessing the rapid growth of the fellowship, Bernese authorities issued orders that demanded the abolition and extermination of the group. Starting in 1527, the government enforced Anabaptist mandates by means of imprisonment and execution. In their efforts to rid the area from Anabaptist influences, officials employed torture, confiscated property, and sent religious believers as galley slaves to the Mediterranean Sea.

In spite of unceasing persecution, the faith group continued to grow. The State of Bern remained a central location for Swiss Anabaptism until the early eighteenth century due to its distinct geographical setting. In the deep valleys and on the more inaccessible homesteads in the Oberland (highland), members of the faith group managed to avoid persecution and carried on their Anabaptist belief and practices for centuries, particularly with the support of sympathetic neighbors and members of the local communities (Gratz 1983,29). At the same time, the group's New Testament-based refusal to take the oath of allegiance and serve in the military was perceived as an act of civil disobedience by Bernese officials and punished accordingly. In reaction to the brotherhood's non-conformity with the secular powers, the Bernese Council formed the Commission for Anabaptist Affairs (Committierten zum Täufergeschäft) in 1659 to carry out measures against the faith group including the banishment of believers from the region. ${ }^{3}$ Although the movement had experienced ostracism and expulsion in various parts of Europe since its beginnings, it was especially the exodus from the State of Bern that left deep marks in the brotherhood's memory.

This regional aspect inspired several Swiss authors to write about the seventeenth-century movement in their homeland. Particularly the events in Bern, the significant gain in the numbers followed by severe persecution, and the substantial support given by sympathetic countrymen provide plentiful material for regional novelists. Fictional writings employing the development of Bernese Anabaptism as a principle theme began to appear in the twentieth century when authors like Rudolf von Tavel rediscovered the movement's tragic fate. His awareness of the region's Anabaptist past is largely due to the efforts of Ernst Müller and his research assistant Adolf Fluri, who helped him to compile the history of Bernese Anabaptism in Geschichte der bernischen Täufer (1895). ${ }^{4}$ Müller, a Reformed church minister in Bern, first came into contact with Swiss Mennonites during his pastorate in the Emmental. His acquaintance with the religious

\footnotetext{
${ }^{1}$ The term "Swiss Brethren" is used in this article according to the definitions provided by Stayer (1991, 95) and Roth (2007, 348 ), in which they refer to both the geographic location in which the movement started and the continuation of its pragmatic and ethical concerns (put to paper in the Schleitheim Articles of 1527) by its successors in the following century.

${ }^{2}$ At that time, Bern was organized as a city-state and often referred to as Stand Bern (State of Bern). Since the use of the term Kanton (canton) for Bernese territory and government only appeared in the eighteenth century, the area will be referred to as State of Bern in this article.

${ }^{3}$ In 1699, the Anabaptist Commission (Täuferkammer) replaced the Committierten zum Täufergeschäft, continuing the work of looking after the confiscated estates of Anabaptists and administering Anabaptist mandates and orders issued by the Bernese government.

${ }^{4}$ In addition to Tavel's historical novel Der Frondeur (1929), Müller's historical account of Swiss Anabaptism also served later fictional texts as a historical foundation. It was a great impetus for Walter Laedrach's Passion in Bern (1938) and Katharina Zimmermann's Die Furgge (1989).
} 
principles and modest lifestyle of the contemporary Anabaptist congregation in that area aroused his interest in the movement's history. In the introduction of his work, he explains the motivations that led to the writing of the Anabaptist history book, namely to offer current congregations a portrayal of their history as one of a martyr church whose existence and strength is gained through its past sufferings (Müller 1895, 2). He paid tributes to the early brotherhood by identifying the believers' self-sacrifice and dedication to values and beliefs as essential aspects of the Swiss character.

This article revisits aspects of the Swiss character and investigates Swiss historical fiction portraying regional Anabaptism with regards to the construction of a national Swiss identity. My critical reading of Rudolf von Tavel's regional novel Der Frondeur ${ }^{5}$ —as a representative example of Swiss fiction dealing with Anabaptist history-explores how the author viewed the religious minority, its commitment to particular theological and ethical precepts, and its confrontations with Swiss society. I question Tavel's use of Ernst Müller's historical research to fashion a particular image of the Swiss Brethren. Moreover, I explore how his personal (Christian) beliefs and concepts of Swiss nationhood influence his fictional portrayal of the minority religion. And, with respect to his objectives, my research seeks to uncover twentiethcentury notions of Swiss nationalism and the construction of a unique Swiss identity cloaked by his literary articulations of encounters between seventeenth-century society and the marginalized group.

\section{Tavel's Commitment to Christian Social Ethics and Civic Duty}

Rudolf von Tavel was one of the first Bernese writers of the twentieth century to be concerned with the history and tragic fate of the Swiss Brethren. To be sure, roughly two decades before his literary portrayal of the peaceful faith group, Ernst Marti told the story of the Emmental Anabaptists in his historical novel Zwei Häuser, zwei Welten (1911). In this narrative, Marti emphasizes the differences between the Swiss Brethren and the state church. The permanent split within a family caused by the Anabaptist controversy symbolizes the irreconcilable views of the two religious groups. While Marti presents the religious minority and the state as two worlds that cannot be united, Tavel advocates rapprochement between the society and the marginalized group as part of his call for a common cause and national unity.

The notion of 'service before self' became Rudolf von Tavel's philosophy of life. As a member of a prominent Bernese patrician family, the author and editor of Berner Tagblatt was concerned with the relationship between society and individual, class barriers between the poor peasants and the rich townspeople, and the state's welfare programs and initiatives (Thomke 1987, 342). ${ }^{6}$ He was highly committed to the matter of "Gemeinwohl vor Eigennutz" "common good before self-interest' in his personal life when he served as a member of the Bernese city parliament and the Association of Protestant Churches, volunteered in the Federation of Swiss

\footnotetext{
${ }^{5}$ The term Frondeur denotes a member of the La Fronde (the name for the "sling" of a children's game played in the streets of Paris in defiance of civil authorities), a political movement in seventeenth century France that opposed the growing power of the royal government. As opponents of absolutism, the fronde movement sought to put a limit to the monarchy. Since the French revolt, the term Frondeur is used both in French and Swiss German to refer to a rebel or a fierce opponent of authorities and government.

${ }^{6}$ Tavel spent his childhood and youth in bourgeois-conservative circles of the city of Bern. In preparation for his time in the secondary school, he was entrusted to the care of a pastor in the small town of Diesbach. During these six months in Diesbach, he gained an insight into rural life and peasantry and developed an appreciation for the strong sense of community and Christian values in the pastor's home (Bräm 1944, 17).
} 
Protestant Churches, and founded Pro Captivis, an aid center for prisoners of war during World War I (Stettler 1967, 196).

In his literary works, Tavel also promoted the idea of common good before individual interests. His novels and novellas reflect ethical convictions that include justice, charity, and service to all of society. Werner Günther $(1963,345)$ has noted that Tavel's depictions of Swiss citizens aspire the ideal of altruism and self-sacrifice for the Volksganze 'the nation as a whole.' In his narratives, Tavel blends his plea for the common cause with a sense of Heimatliebe 'love of homeland' - the glorification of the Bernese countryside and its people. His demand for respect and support for all of Switzerland's inhabitants is closely related to this love for his homeland (Bräm 1944, 92). He realizes that such a unity among all people, deriving from his ideal of national unity and identity, can only be achieved if the values, opinions, and beliefs of each individual are respected and honored - a notion that is imperative in a state like Switzerland where a diversity of languages, religious denominations, and cultures has historically grown.

The concept of the individual and his/her civic duties to the state functioned as a lens through which Tavel perceived the history of his nation and life in general. Beginning in childhood, the author was fascinated with Switzerland's development toward a confederacy. During his school years, he wrote short stories describing military events that led to the foundation of the Swiss Confederation. Many of his regional novels depict the State of Bern in the seventeenth century, particularly during the time of the Swiss peasant war of 1653 and the Second Battle of Villmergen in $1712 .^{7}$ Hugo Marti $(1955,185)$ has asserted that in each of Tavel's historical novels was a recurring, deepened, always passionate invocation of Bernese history as if coping with the present age could only be accomplished through the optics of the region's past experiences. In the unpublished foreword to his novel Der Frondeur, Tavel elucidates the similarities between the present and the past. ${ }^{8} \mathrm{He}$ felt drawn to array contemporary issues in a historical costume to eliminate "das Gezänk der Gegenwart" "the bickering of the present,' and to enable the reader to approach the subject matter without inhibition (Stettler 1967, 189). Such bickering, as he called the political and social discord prevailing in early twentiethcentury Switzerland, was caused by tensions between Federalist and Unitarian factions. The country faced social problems that originated in insufficient integration policies. ${ }^{9}$ With his literary depiction of religious and territorial disputes in the seventeenth century, Tavel attempts to address the contemporary problem of integrating all citizens into the Swiss state.

Tavel's historical novels do not only connect the present with the past by depicting issues that remained problematic for Swiss society, especially the struggle to unify the diverse population; the author also made history accessible to readers by writing most of his stories in

\footnotetext{
${ }^{7}$ See, for instance, Ja gäll, so geit's (1903), Der Stärn vo Buebebärg (1907), D'Haselmuus. E Gschicht us em Undergang vom alte Bärn (1922), and Ring i der Chetti. E Läbesgschicht (1931).

8 "Was unsere moderne Welt bewegt, findet trotz den Fortschritten der Zivilisation immer irgendwo in der Geschichte seine Parallelen ... Eine Parallele fand ich ungesucht zwischen unserer Nachkriegszeit und der Zeit der absoluten Staatswirtschaft nach dem 30jährigen Krieg, in welcher eine zugleich weitsichtige und väterlich-ängstliche Politik unser Vaterland regierte" 'despite civilization's progress, those aspects that determine our modern world always have parallels to history ... without searching, I found a parallel between our post-Great War period and the time of political absolutism after the Thirty Years' War in which both farsighted and paternal-scrupulous politics ruled our homeland' (Tavel BBB 16, "Frondeur").

${ }^{9}$ Despite integration efforts with respect to religious, cultural, and linguistic differences, not all citizens were able to identify fully with the Swiss Confederation since none of these state programs took social class into consideration (Thomke 1987, 341).
} 
the Bernese dialect. ${ }^{10}$ The familiar language bridges the gap between the novels' historical settings and the contemporary audience and creates a sense of kinship between the reader and the fictional characters. ${ }^{11}$ By enriching his narratives with the familiar tongue and descriptions of regional landscapes, figures, and lore, Tavel seeks to capture the "bernische Volksseele" 'Bernese ethnic soul' (Marti 1955, 185). In accordance with his ideal of national unity, he integrates a variety of social, religious, and cultural elements into his literary portrayal of the Bernese character.

\section{National Unity and the Construction of Swiss Identity}

Switzerland stands apart from many other European nations due to its linguistic pluralism and regional diversity. As a poly-ethnic nation-state, Switzerland challenges traditional models of modern nations as communities of shared language. In fact, Benedict Anderson (1991) claims that the country did not engage in any national identity politics (he refers to it as nationalism) whereby nationhood is (re)constructed, worthy of the name until 1900. He explains that Swiss national identity "arose in that period of world history in which the nation was becoming an international norm and in which it was possible to 'model' nationness in a much more complex way" (p. 139), enabling Switzerland's survival as a nation in spite of its poly-ethnic composition.

National identity is called into question during unsettled historical phases in which competitive public struggles form over the definition of nationhood. One of these unsettled phases took place during the 1930s when Switzerland faced the challenge of nationhood posed by the volkish and highly aggressive pan-Germanic nationalism of the Nazis. Prior to the rise of fascism in Europe, parts of the Swiss population had already felt that Swiss nationhood was underdetermined and needed stabilization. This late nineteenth-century effort to forge a national identity utilized specific sets of symbolic resources to create a sense of solidarity among Swiss citizens.

While most homo-ethnic nations create national identity by observing historical and ethnocultural traditions such as common language, religion, shared historical experiences, and genealogical descent, nineteenth century Switzerland pursued a civic (or political) conception of nationhood in which the nation is seen as rooted in the institutional framework that constitutes the modern state. According to Zimmer (2003, 8-9), civic conceptions of nationhood prioritize first and foremost political institutions before considering additional symbolic resources such as culture and history. Organic (as Zimmer calls ethno-cultural) conceptions of national identity formation, on the other hand, focus on geography (aspects of homeland, landscape, and nature), history, and culture. Switzerland's attachment to fundamental political institutions and values in the late nineteenth-century was insufficient to form and reproduce national identity. Only the amalgam of political and cultural features secured the country's national unity by building collective loyalty to the state.

In fact, the organic view of national Swiss identity was prevalent in elite circles and in discourse of right-of-center groups during the 1920s. Particularly, the natural environment

\footnotetext{
${ }^{10}$ After having penned a few dramas in standard German, Tavel started writing narratives in the dialect spoken in the city of Bern. He commented on his choice of language that it was a fortunate incidence by which he discovered his very own writing style (Marti 1955, 115).

${ }^{11}$ As Settler $(1967,189)$ has asserted quite poetically, with the use of the Bernese dialect, the historical perspective flees like a autumn mist from the warm rays of the sun.
} 
became a vital symbolic resource for the construction of Swissness. Alpine landscape was accentuated "as a distinctive characteristic of Swiss national identity, an area for the projection of myths, memories, and virtues" (Eugster and Strijbis 2011, 402). The character shaping force of Switzerland's natural environment - in lieu of common ancestors or language - was expounded by Gottfried Keller in his novel Der Grüne Heinrich (1854), in which he declares that "the natural beauty of Switzerland was a reflection of historical and political merit and of the patriotism of the Swiss people: an equivalent of freedom itself' (quoted from Jost 1988, 18-19). The Alps provided a source of national authenticity and turned into a popular national symbol of Switzerland between 1870 and the end of World War II. This natural environment, especially the Alpine community, was related to common values of diligence, humility, and solidarity. In the following reading of encounters with Swiss Brethren in Tavel's regional novel Der Frondeur, conceptions of civic and organic nationhood and the Alpine myth of shared memory and virtues are applied to identify the author's notions of national unity and peculiar feeling of a common homeland.

\section{Encountering Swiss Brethren in Der Frondeur}

Set in the Bernese Alps in the second half of the seventeenth century, the novel tells the story of Heros von Herbort, a Swiss mercenary who returns to his wife and children after having fought for six years in the Thirty Years' War. While serving as an officer of the Swiss regiment abroad, he accumulated a fortune that he wants to invest in the remodeling of his residence. During an excursion in the nearby forest, he and his children encounter a remote settlement belonging to Swiss Brethren. As they watch the congregants return from a community meeting, Heros expresses his appreciation for the brotherhood's simple and pious life. After he and his children return from their hike, two councilmen pay him a visit and ask him to become a member of Bern's City Council. Heros, however, refrains from politics and pursues his work on redesigning his property. Since these ambitious remodeling plans soon exceed his budget, he decides to leave his family once more to serve as a mercenary soldier in Italy.

During his absence, the city council issues sharp Anabaptist mandates that result in the imprisonment, torture, and expulsion of the brethren in the Emmental. Heros' son Gideon, who lacks discipline and guidance, neglects his responsibilities on the family estate. Instead, he goes out drinking and reveals the names of local brethren to state authorities. Meanwhile, Heros is imprisoned after he demanded the release of Swiss Brethren who were sold by the Bernese government to work as oarsmen on Venetian galleys. He had discovered these fellow countrymen when he petitioned the Venetian Court for residual payments for his regiment. When he does not return to Bern with his regiment of mercenary soldiers after their service in Venice, his wife Nicolette succumbs to her pain and sorrow.

Only after a complaint from Bern's City Council is Heros eventually permitted to leave Italy. He returns home to find his son dead. After the funeral procession, he passes the settlement of Swiss Brethren and is reminded of their fate as galley slaves in Italy. He realizes that he bears responsibility for his fellow countrymen. In order to rescue the Swiss Brethren from their slavery in the Mediterranean, Heros decides to join the council.

Tavel wrote this novel in the aftermath of World War I. His service in the aid center for prisoners of war left a profound impression on him and inspired him to address the issue of 
returning soldiers in his novel about seventeenth-century Switzerland. ${ }^{12}$ Yet, his plans to treat this historic subject matter in the form of a narrative came much earlier. In a letter to a friend, Tavel mentioned that he had thought about combining the motif of returning home with the Thirty Years' War since the 1890s. After World War I, he was able to empathize with those returning home from foreign countries - those with broken masts, torn flags, and shattered dreams (Marti 1955, 138). The experience of World War I and the development of new national identities thereafter reconfirmed Tavel's belief in the importance of unity within the state. In numerous writings collected in his literary estate at the Burgerbibliothek Bern, he stresses the notion of "Staatsfriede" 'peace of the state' (BBB 21.5). Analyzing the armed conflicts in the early modern history of Switzerland, he became aware of their unifying dynamism and attempted to fictionalize the "einheitsstiftende Kraft des Krieges" 'the unifying power of war' in his historical novels (Thomke 1987, 344).

In these narratives, Tavel attempted to fuse patriotism with the spirit of Christian social ethics (Thomke 1987, 343). Throughout his life, he was a dedicated member of Bern's Evangelical Reformed Church ${ }^{13}$ and expressed his Christian convictions in an open and public manner. In his essays and talks on the church and religion, he discussed the idea of a "frommer Söldner" 'devout mercenary', and the responsibilities of the congregation in post-war periods (BBB 143-69). ${ }^{14}$ According to his biographer, he perceived faith not as dogmatic religiousness, but rather sought Christianity of deeds which he considered the best of humanity with its magnanimity (Marti 1955, 62). Deriving from the notion of a practical faith, he understood Christ's sacrifice on the cross as a call for service to the city, the country, and its people (Stettler 1967, 199). This service aimed to ensure the well-being of the entire society, including social and religious minorities.

The pursuit of unifying the Swiss people, regardless of their denomination or social status, became the principal theme of Tavel's novel Der Frondeur. Inspired by Müller's sympathetic account of the Anabaptist movement in the State of Bern, the novelist draws a literary picture of the brethren that reflects their peaceful and pious manner of life as well as their suffering from ostracism and persecution by the dominant society. At first reading, the Anabaptist image drawn by Tavel is one of respect, empathy, and solidarity. Unlike earlier fictional representations of Swiss Brethren, for instance Gottfried Keller's stigmatization of the movement as a fanatical and grotesque sect in his historical novella Ursula (1877), Tavel demonstrates understanding for the persecuted brethren in his homeland. Indeed, the Mennonite Encyclopedia refers to Der Frondeur as "an excellent novel ... [that] discusses incidentally the Mennonites of the Emmental" (Schowalter, et al. 1956). While there is no disagreement with the quality of the novel itself, a close reading of the work and Tavel's notes, however, reveals that the discussion of the faith group is by no means "incidental." Rather, the author carefully selected aspects of Anabaptist piety and experience to design an image of the faith group that supports his empathetic call for national unity.

\footnotetext{
${ }^{12}$ In a discussion of Tavel's oeuvre, Günther $(1963,343)$ has pointed out that the experience of war brought about a change in the quality of the author's writings; his literary works in the 1920 s are characterized by a thoughtful nature.

${ }^{13}$ In Bern, he served as a member of the parochial church council and cantonal church synod. Later, he was elected into the administrative board of churches (Bräm 1944, 25).

${ }^{14}$ See for example: "Welche Aufgaben warten der Kirche nach dem Kriege?" 'Which tasks await the church after the war'; "Der Christen Dienstbarkeit und Ehrenpflicht in der Gemeinde" 'Servitude and obligation of honor of Christians in the Community'; and "Christ und Soldat" 'Christian and Soldier' (collected in the author's literary estate).
} 
The Swiss Brethren are first introduced in the novel as a small fellowship that meets in a place hidden in the remote area of the Bernese Oberland. The group arouses the interest of the protagonist and his children who, taking a break during their morning hike, observe how young and old people leave a farmhouse in a single file and disperse into the vicinity:

„Lueget da unde? Was isch da los?” I halber Höchi vom Bärg chöme Lüt underem Vorschärme vomene Burehus vüre. Im Gänslimarsch gange si uf mene schmale Wägli dem Bort nah. Alti Manne mit Chranzbärt, jungi, chreftigi Bursche, Froue, e längi, längi Zylete ... Si verteile sech und verschwinde nah-ti-nah. "I weiß, was das isch," seit der Herr Heros, "das sy Täufer. Die hei gewüß hie ne Versammlung gha." (84)

"Look down there? What is going on there?" About half way up the mountain, people appeared from a farmhouse. In a single file they walked the narrow path along the slope. Old men with circle beards, young, strong men, women, a long, long line of people ... They disperse and disappear bit by bit. "I know who these are," Heros said, "those are Anabaptists. They must have had a meeting here." 15

The congregation depicted in the novel used an isolated building on the edge of the forest to gather for a worship service. Noticing the quiet manner by which the group of people leaves the remote farm in a single line, Heros identifies them as Täufer 'Anabaptists' and concludes that they had gathered for an informal church meeting, a practice that is prohibited and punished by the Bernese government. To his son question “Isch das nid verbotte?" 'that's illegal, isn't it?', Heros responds: "Si trybe nes gfährlechs Spil. Aber lue, wenn me gseh und erläbt het, was I, so lehrt me d'Lüt la mache" (p. 84) 'They are playing a dangerous game. But if you had experienced and seen what I have experienced and seen, you would just let those people be.' He acknowledges that these secret gatherings are indeed unlawful; at the same time, he admits to his children that he is not opposed to the group's peculiar church practices. Through his experience in the Thirty Years' War, he received a broader view of religious toleration than most of his fellow countrymen, especially those who serve in the Bernese City Council that issues harsh mandates against the brotherhood.

Heros continues with his thoughts on the religious minority and even expresses a sense of appreciation for the brethren's genuine faith and way of life. He asserts: "Wär weiß, ob die dahinde nid besser verstande, was ne der lieb Gott z'säge het, als mir i üsne Chilche, wo di Herre Predikante mängisch besser wei wüsse, was i der Bibel steit, als Gott sälber' (pp. 84-85) 'Who knows, perhaps they have a better understanding of God's words than we do at our church in which the predicants [assistant preachers in Protestant churches] occasionally seem to be better informed about Bible content than God himself is.' His sarcastic comment on the preachers' claim to Christian superiority reflects a widespread frustration with the state church. Heros questions the theological education of Reformed Church leaders and criticizes their presumption of divine knowledge. ${ }^{16}$ He suggests that the brethren have greater insight into God's will than the learned clergy, an assumption that he shared with some neighbors who sympathized with the group and supported them during times of harsh persecution. ${ }^{17}$

\footnotetext{
15 All quotations of Tavel's novel are translated by the author.

${ }^{16}$ Müller's (1895) historical account of Bernese Anabaptism mentions a similar criticism voiced by Katharina Zell (wife of the Straßbourg reformer Matthias Zell) who blamed the Reformed preachers and their lives and doctrines for Anabaptists' withdrawal from the state church (p. 3).

${ }^{17}$ According to Gratz (1983), many of the Anabaptists' neighbors regarded the brethren highly and much of the rural populace thought of them as "saints and persons who had experienced true salvation" (p. 50).
} 
In his positive account of the Swiss Brethren, Heros also comments on their practice of believer's baptism: "Und daß si sech im Wasser vo ihrne Bärgbech löi toufe-warum nid? Das gfallt mir de no grad. Das ghört so derzue. Es isch alles so wahr und luter by ne" (p. 85) 'And that they get baptized in the water of the mountain stream — why not? I particularly like that. That's just simply part of it. Everything is so true and sincere.' The protagonist speaks in favor of the brethren's initiation ritual without referencing to its implications, namely the concept of church as a voluntary fellowship for those who commit themselves to discipleship, brotherly love, and separation from worldly enticements. Rather, his reference to the mountain stream creates a romantic image of the group as isolated mountain folk who lead a simple life close to nature. Heros and his children encounter these Swiss Brethren during their excursion to the local mountain. Quite naturally, the protagonist associates them with the rural area and regards their baptism in a stream as part of their genuine Swiss character and closeness to nature that he particularly favors. In search for an organic nationhood, the author applies notions of geographical determinism in which a (national) character receives its peculiar cast from natural scenery. The specific landscape of the Bernese Oberland evokes a spiritual and moral transformation capable of providing Switzerland with a unified form.

During this first encounter with the Swiss Brethren, the question of Heros' son whether "sy ächt üsi Hirten o derby?" 'Are our eight shepherds among them?' points to the social disparity between the protagonist and the marginal group (p. 85). While Heros ${ }^{18}$ is a respected burgher of Bern who owns a large piece of property and hires help to tend the land and cattle, the Swiss Brethren are members of the lower social stratum who serve as farm hands for the affluent ruling class. In that regard, the relationship between Heros and the brethren is determined by social differences as well as urban-rural and power relations. Despite his higher social and economic standing, however, he expresses sympathy for the group when responding to his son Gideon's question: "Es chönnti wohl sy. I frage se nid. Es sy bravi Lüt, und me mueß se nid welle ga besser mache" (p. 85) 'That could well be. I will not ask them. They are good people and it's not on us to make them even better.' In accordance with Tavel's notion of Volksganze - the unity among Swiss people - the protagonist acknowledges the brethren's good and honest nature and promotes tolerance toward the marginalized group.

In this encounter between the protagonist and the religious minority, the author introduces the Anabaptists as simple, honest, and faithful people who exist on the periphery of the Bernese society. As social outsiders, they live in Bern's remote countryside and can only be observed from a distance. Gideon's questions demonstrate how the dominant society perceives them as outcasts. Yet, the protagonist shows sympathy and appreciation for the marginalized group. As he observes the Swiss Brethren from the top of a hill, he considers their practical faith and moral conduct ("bravi Lüt"). This act of seeing implies his recognition and perhaps even understanding for their distinct faith and manner of life. At the same time, the act of looking from the top of a hill down to the dispersing group of people symbolizes the power dynamic between him and the minority. In the visual discourse of Western culture, the emphasis on looking from the top down is generally regarded as a "mastering, colonizing gaze" (Bal 2009, 19). Heros assumes the role of the master who oversees the persecuted brethren and simultaneously watches over them, a role that becomes more pronounced as the story continues.

\footnotetext{
${ }^{18}$ The name Heros (Greek, singular form of "hero") anticipates the protagonist's heroic mission in which he sacrifices his own good to rescue the persecuted minority and thus contributes to the greater good of society.
} 
Shortly after this first encounter, the protagonist offers the issue of Anabaptist persecution as an explanation for his unwillingness to serve as a member of the council. His experience in the war has changed his perspective on the state and led him to a different understanding of civil responsibility and treatment of religious nonconformists. The persecution of the brotherhood causes a blemish on the state's record which provides him with reasons to object to the Bernese government, much in accordance with the novel's title Frondeur (fierce opponent of the government). When asked by the councilmen whether or not he sides with the "Sektierer" 'separatists, ${ }^{19}$ Heros voices criticism against the state's anti- Anabaptist policies and declares that authorities should not find fault with the religious group, but rather look at the corruption within the state church:

Me sötti äbe nid vergässe, wär d'schuld isch a der Sektiererei. Wären üsi oberkeitleche Pfarrer, wie si sy sötte, so gäb's im Bärnerland keini Täufer. Aber lueget, wär vo Chindsbeinen a sys Brot im Härd suecht und mit Sunneschyn und Räge mueß rächne, versteit sech besser uf Gott und d'Schrift als eui schwarze Manne, wo ihri ganzi Inschpiration z’Bärn im Rathus sueche. Was i vo Töufer gseh ha-und i kennen ere meh Aug in Aug als di Herre z’Bärn- sy bravi Lüt. Si hei meh Disziplin als mänge Pfarrer. (p. 92)

One should not forget who is to blame for separatism. If our superior pastors would behave the way they should, we would not have any Anabaptists in the State of Bern. But look, these people whostarting at an early age - need to search for some sweet bread in the stove and face sunshine and rain, get along with God and Scripture better than our men in black who receive all of their inspiration in Bern's townhall. The kind of Anabaptists I have seen - and I know more of them personally than the gentlemen at the townhall — are good people. They are more disciplined than some of the pastors.

Having observed the rural populace, Heros has been profoundly impressed by the simplicity and sincerity of the group's Christian faith as compared to the clergy's dearth of genuine inspiration and lack of moral propriety. Through the protagonist's sympathy for the brethren's simple life and Christian practice, Tavel stresses their ethics of good works as it relates to his own notion of Christianity of deeds. Depicting them as simple and practical believers whose Christian faith is primarily reflected in their ethical conduct and rural modesty, he arouses admiration and empathy for the Swiss Brethren.

However, Heros is the only character in the novel who appreciates their practical faith. The Bernese government and townspeople do not share his sympathy for the marginalized group. Rather, they treat the believers as outcasts, ridicule their simple and rural nature and persecute them, or simply avoid any contact with them for fear of being labelled sympathizers of the group. Even Heros' wife Nicolette maintains a strict separation between her family and the brethren, as she is concerned about the social and economic ramifications of being associated with them. Worried about putting her husband's high standing in the Bernese society at risk, she treats the local group as outcast and warns her children to stay away from its' members. Despite her concerns for the family's reputation, she acknowledges the group's peaceful character, noting: "Nid nume tüe si niemerem nüt z'leid, si sy im Gägeteil e Säge für ds Land" (p. 148) 'not only are they not harming anyone, in fact, they are a blessing for the country.' She further describes

\footnotetext{
19 The term "Sektierer" was particularly employed by the state and church in the seventeenth and eighteenth centuries to emphasize the movement's marginal and deviant nature manifested in a divergent belief, rejection of domination by state and state church, and separation from the world through the idea of the two kingdoms. The dominant church used the term in a derogatory way, implying "heresy and schism, together with denial of sacerdotal claims" (Wilson 1976, 16).
} 
them as "arme, plagete Lüt" (p. 149) 'poor, afflicted people,' who suffer from discrimination by the state and its people.

The image of the Anabaptists as afflicted people is taken to a new level by the depiction of encounters with group members on the Venetian galleys. The Swiss Brethren are marked by the painful experience as galley slaves, a punishment that was feared nearly as much as the death sentence:

Im Hofe usse lige di Zsämegchetteleten usem Pflaschter i der Sunne. Di einte hei sech scho ergä gha i ihres truurige Gschick. D’Lyde vom Transport hei ihre Widerstand broche. Aber dä Offizier, wo ganz unvermuetet da erschinen isch, het usgseh wie-n-e Mäntsch ... da schlat ändlech wieder es Härz. Und e Schweyzer isch es. (p. 344)

In the courtyard, the men that are chained together are laying on the cobbled pavement in the sun. Some have already surrendered to their sad fate. The sufferings during their transport broke their resistance. But the officer who showed up all of a sudden looked like a human being ... their hearts finally start beating again. And a Swiss, it is.

After their agonizing journey to Venice, many of the brethren in Tavel's novel are shown to have lost all hope and to be resigned to their fate. In his depiction of their arrival in Italy, the author received inspiration from Müller's account of four Swiss Brethren from Bern who were sentenced to work as oarsmen on the Venetian galleys in 1671. Müller mentions that these four men were repeatedly given the chance to recant and be sent back to Switzerland during their passage to Italy, but that they remained steadfast. Tavel, however, does not include any references to the men's persistence in their faith and their willingness to bear all suffering rather than renounce their Anabaptist belief. Instead, he depicts them as hopeless convicts who have fallen victim to anti-Anabaptist politics in Bern. The narrative credits the presence of the Swiss officer Heros, rather than their distinct faith with providing them with a sense of hope and encouragement.

In his historical research, Müller also mentions Herr Georg Orell, a Swiss military officer who was assigned with the task of petitioning residual payments of the Swiss mercenary regiment at the Venetian Court at the same time these brethren arrived as galley slaves (p. 219). When reading Müller's description of the officer's mission in Italy, it becomes obvious that the character of Heros is based on this historical figure. While Orell reports on the arrival of the brethren to the Bernese government without intending to rescue these men, Tavel fictionalizes this historical encounter and suggests the officer's concern with the persecuted brethren. Tavel leaves out the brethren's steadfastness and fabricates Heros' attempts to free the Anabaptist countrymen as a vehicle to represent the protagonist's development toward a heroic Swiss figure. The fictional character of Orell is put on a literary pedestal and becomes subject to the author's projections when he depicts his dedication to the suffering brethren as an act of loyalty and unity among the Swiss people. Heros enters the scene of despair and resignation as a "Schweyzer"-a fellow Swiss who comes to save the Swiss Brethren who - according to the historical text — did not seek rescue and saving from the galley.

In Tavel's fictional account, the Swiss Brethren regard Heros as a savior who comes to rescue them from the terrible life of slavery. Once they recognize him as a fellow Swiss, they embrace him, quite literally, and beg him on their knees for help (p. 343): 
Di beien andere Töufer fallen uf d'Chneu und stricken ihri einti, freji Hand na-n-ihm us. Er fasset se, di Händ, wo sech a de Ringgisbörter hert gwärchet hei, und findt schier d'Stimm nid ...Die drei andere jammere, er söll sech erbarmen und ne hälfe. (pp. 343-44)

The other two Anabaptists fall on their knees and stretch out their only free hand to him. He takes their hands - with which all of these Riggisberg men have worked hard — and has no words ... the other three men moan, asking him to have mercy and help them.

By this quasi worshipful act of falling to their knees and reaching out for Heros, they assume a submissive position in which they utterly rely on the officer's sense of charity. The moment he turns toward them and takes them by the hand marks his conversion to an actively committed Bernese burgher, devoted to caring for the needs of these persecuted countrymen. The physical contact of taking them by their hands symbolizes a unity between him and the Swiss Brethren that corresponds to Tavel's vision of unity among all Swiss people. The brethren Heros once watched from a distance are now in immediate proximity as they gather around him. Despite the physical closeness to the believers, this situation reiterates social hierarchy and power relations between the officer and the captives. Heros assumes an elevated position in which he is now surrounded by members of the faith group whose lower social standing and dependence on his mercy is indicated by their act of prostration.

Tavel's fictionalization of an account drawn from Müller's chapter 'Auf die Galeeren!', his literary treatment of Anabaptist persecution in form of galley slavery and Heros' decision to free these subjugated people, supports his vision of a unifying Swiss identity, in which the individual desists from selfish interests and, instead, contributes to the common cause. Heros could have prevented the harsh Anabaptist persecution, if he had committed to serving in the City Council rather than in the Swiss regiment abroad. As a dedicated burgher of Bern, he could have protected the marginalized faith group. Instead, he left his hometown to pursue selfish interests such as fame and fortune. He only becomes aware of the degree of damage caused by his insufficient commitment when he discovers the horrible fate of the brethren in Italy. In his depiction of Heros' neglect of his responsibilities as a father, husband, and member of Bernese ruling society, Tavel addresses the theme of guilt and expiation and makes the Anabaptist persecution a consequence of the protagonist's selfish conduct.

\section{Conclusion}

Corresponding to Tavel's concept of the individual and the common cause, the protagonist takes initiative and fulfills his civic duty as a committed burgher of Bern. The brotherhood's persecution by the state becomes a means of convincing him to desist from selfish interests and instead to contribute to the state's unity. ${ }^{20}$ While the author addresses the group's persecution in the State of Bern, he does not fully illuminate the reasons for the state's hostility against the faith group. He depicts them as poor and oppressed people whose place within Bernese society is determined by their role as outsiders. They are spatially and socially separated from society and pictured as victims of discriminatory politics. Tavel illustrates their endurance of pain on the Venetian galleys without, however, referencing to the religious connotation of their persistence. In fact, he leaves out their steadfastness reported in Müller's study and replaces it with despair while elevating the protagonist with a sense of Swiss solidarity.

\footnotetext{
${ }^{20}$ As the author has noted in the "Dispositionsplan" to Der Frondeur, the concept of "Schicksal" 'fate' and "Gnade" 'mercy' determine Heros development as the main character (BBB 21.5).
} 
When analyzing images of Swiss Brethren in fictional literature, the existence of characteristic features of Anabaptist piety and practices becomes equally important as the absence thereof. Der Frondeur fails to include the political implications of the Anabaptist theology as manifested in the group's refusal to participate in militant actions and swear the oath of allegiance. It fails to reference to the movement's theology of two kingdoms exemplified by their rejection of the established church as a way of maintaining the boundary between themselves and the world. Rather, it creates an image of the Swiss Brethren as persecuted outsiders who can only be saved by the protagonist's effort to establish unity among all inhabitants of the Swiss state. The depiction of their misery simply serves the purpose of calling the protagonist's attention to his responsibilities as a Bernese burgher. By depicting Heros as a protector of the persecuted minority, Tavel creates a relationship of dependency between the protagonist and the brethren. His heroic actions of attempting to free the enslaved believers and wanting to join the City Council to advocate for their inclusion are colored by a dominant paternalistic stance with which the Bernese elite assumes their position as ruling class. In his effort to secure legitimacy of certain power elites (of past and present), the author replaces the nonconformist nature of the minority with a fabricated nature of submission.

In his historical fiction, Tavel contributes to the construction of a national identity by engaging in partial memory with the purpose of molding a modern Swiss identity. He excavates and presents to the reader aspects of a communal past to regenerate a sense of community. Yet, he is selective in this task, leaving out important tenets of Anabaptist faith and practice while accentuating the association with the specific Swiss/Alpine territory and the solidarity among its people. As he erects the historical hero in his fiction and characterizes him as an ally to the persecuted minority, he is involved in shaping a modern Swiss cultural identity from the perspective of the dominant society for the purpose of establishing a sense of unity among the diverse groups of contemporary Swiss citizens. In his description of Heros' conversion to the political office after witnessing the deplorable situation of fellow Swiss in Italy, Tavel appeals to civic notions of nationhood in which democratic institutions are emphasized and a narrative of Switzerland as a voluntary nation is developed. He assures the readers to put their trust in the political culture and state institutions as they derive from a long tradition of loyalty and commitment as exemplified by the character development of the hero in the novel.

Additionally, Tavel utilizes the natural environment (or more precisely: the Bernese Oberland) as a proposed origin for certain shared values and inherited ways of life. Beyond all social boundaries and differences in religious practices, the Alpine nature becomes a unifying agent that creates a bond between the hero and the ostracized brotherhood. Heros does not primarily campaign for the rescue of a persecuted religious minority but for the freeing of fellow countrymen with whom he shares similar virtues and a deep affection for their common homeland. The Swiss Brethren are worthy of saving, not because of the inhumane condition on the galleys or their ostracism by the dominant Swiss society; rather, they become the focus of Heros' efforts due to the deep connection between him, his homeland, and its people. The fictionalized encounter with the Swiss Brethren raises a sense of civic duty and shared history that nurtures a unified Swiss identity. 


\section{References}

Anderson, Benedict. 1991. Imagined Communities. Reflections on the Origin and Spread of Nationalism. New York, NY: Verso.

Bal, Mieke. 2009. Narratology. Introduction to the Theory of Narrative. 3rd ed. Toronto, ON: University of Toronto Press.

Bräm, Max E. 1944. Rudolf von Tavels Werk als Ausdruck schweizerischen Denkens und Empfindens. Bern, Switzerland: Francke Verlag.

Eugster, Beatrice, and Oliver Strijis. 2011. “The Swiss: A Political Nation?” Swiss Political Science Review 17:394-416. https://doi.org/10.1111/j.1662-6370.2011.02029.x

Gratz, Delbert. 1983. Bernese Anabaptists. Goshen, IN: The Mennonite Historical Society.

Günther, Werner. 1963. Dichter der neueren Schweiz. Vol. 1. Bern, Switzerland: Francke Verlag.

Jost, Hans-Ulrich. 1988. "Nation, Politics, and Art." Pp. 13-21 in Liotard to le Corbusier. 200 years of Swiss Painting, 1730-1930, edited by the Swiss Institute for Art Research on behalf of the Coordinating Commission for the Presence of Switzerland Abroad, Zürich.

Marti, Hugo. 1955. Rudolf von Tavel. Leben und Werk. Bern, Switzerland: Francke Verlag.

Müller, Ernst. 1895. Geschichte der Bernischen Täufer. Nach den Urkunden dargestellt. Frauenfeld, Switzerland: J. Hubers Verlag.

Roth, John D. 2007. "Marpeck and the Later Swiss Brethren, 1540-1700." A Companion to Anabaptism and Spiritualism, 1521-1700, edited by John D. Roth and James M. Stayer. Leiden, Netherlands: Brill.

Schowalter, Otto, Mary Eleanor Bender, Pierre Sommer, and Harold S. Bender. 1956. "Literature, Mennonites in - Germany, Austria, Switzerland, and France (to 1950s)." Global Anabaptist Mennonite Encyclopedia Online. Retrieved Jun 23, 2018 (http://gameo.org/index.php?title=Literature, _Mennonites_in_--_Germany,_Austria,_Switzerland,_and_France_(To_1950s)\&oldid=146580).

Stayer, James. 1991. The German Peasants' War and Anabaptist Community of Goods. Montreal, Quebec: McGill-Queen's University Press.

Stettler, Michael.1967. Neues Bernerlob: Versuche zur Überlieferung. Schriften der Berner Burgerbibliothek. Bern, Switzerland: Stämpfi \& Chie.

Tavel, Rudolf von. 1929. Der Frondeur. Berndeutscher Roman aus dem 17ten Jahrhundert. Bern, Switzerland: A. Francke Verlag.

—. "Dispositionspläne." BBB N Tavel 21(5), ts. Rudolf von Tavel Papers. Burgerbibliothek, Bern.

—. "Kirchliche Ansprachen und Aufsätze." BBB N Tavel 143-169, ts. Rudolf von Tavel Papers. Burgerbibliothek, Bern, Switzerland.

-. "Manuskripte. Der Frondeur." BBB N Tavel 16, ts. Rudolf von Tavel Papers. Burgerbibliothek, Bern.

Thomke, Hellmut. 1987. "Patriotische Dramatiker des ausgehenden 19. Jahrhunderts der Junge Rudolf von Tavel und Arnold Ott." Pp. 337-51 in Auf dem Weg zu einer schweizerischen Identität 1848-1914. 8. Kolloquium der Schweizerischen Akademie der Geisteswissenschaften, edited by Schweizerische Akademie der Geisteswissenschaften. Freiburg, Switzerland: Universitätsverlag.

Wilson, Bryan. 1970. Religious Sects: A Sociological Study. New York, NY: McGraw-Hill Company.

Zimmer, Oliver. 2003. A Contested Nation. History, Memory, and Nationalism in Switzerland, 1761 1891. Cambridge, UK: Cambridge University Press. 